\title{
American Horticultural Therapy Association: Its Purpose and Potential
}

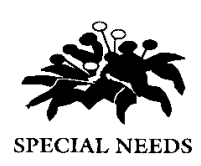

Steven H. Davis ${ }^{1}$

$\mathrm{H}$

orticultural therapy is a medical discipline that uses plants, gardening activities, and the innate closeness we all feel toward nature as vehicles in professionally conducted programs in therapy and rehabilitation (Davis, 1994a). Everyone who enjoys gardening knows that being close to the soil fulfills a certain basic human need. Gardening enhances physical condition, relieves frustration, provides a sense of accomplishment, improves mental health, and provides great joy. The therapist who is trained in horticulture uses this people-plant connection as a foundation from which to improve human health and well-being (Davis, 1994 b).

Although using gardening as a therapeutic tool in the United States can trace its beginnings back to the early 1800s (O'Conner, 1958), a true medical profession did not begin to emerge until the 1940s. It was during World War II, in veterans hospitals, that the vehicle of horticulture in therapy and rehabilitation programming became recognized as a new and distinctly separate adjunctive therapy (Tereshkovich, 1975).

However, for much of the next 30 years, horticultural therapy underwent a laborious process of trying to attach a complete definition to its name. During this exploration period, new applications in horticultural therapy were tested with people of all ages and with every imaginable disability at hospitals, rehabilitation facilities, retirement centers, and even correctional institutions. It was during this time that horticultural therapy's considerable breadth of application became understood and its separateness from occupational therapy became substantiated. During these 30 years, the horticultural therapists of the time collectively gave birth to the profession that exists today. 


\section{Educational opportunities}

During these same years, educational opportunities in horticultural therapy also began to evolve. In 1942. Milwaukee Downer College, the first college to award a degree in occupational therapy, became the first institution of higher learning to offer a course in horticulture within an occupational therapy degree program. Thirteen years later, in 1955, Michigan State Univ. became the first institution to award a MS in occupational therapy that included an emphasis in horticulture. In 1972, through a cooperative program between the Activity Therapy Dept. of the Menninger Foundation and the Horticulture Dept. at Kansas State Univ., the first curriculum specific to horticultural therapy was instituted. 'This program combined formal training in psychology and horticulture at Kansas State Univ. with 7 months of clinical experience at the Menninger Foundation (Tereshkovich, 1975).

Although similar academic programs soon followed at Clemson Univ. and Michigan State Univ., these additional programs proved to be short-lived. Today, the undergraduate degree program at Kansas State Univ. is the only such ongoing degree program in the United States. Eleven other institutions of higher learning currently offer horticultural therapy coursework, 1-year programs, or options within horticulture. The Univ. of Massachusetts, Tulsa Junior College, Tennessee Technological Univ., Temple Univ., Rockland Community College, and Massachusetts Bay Community College offer coursework. Edmonds Community College offers a 1-year program, and MS or BS options in horticulture are offered by Virginia Polytechnic Inst. and State Univ., Univ. of Rhode Island, Texas A\&M Univ., Herbert H. Lehman College, and The City Univ. of New York. Although the number of highereducational opportunities in horticultural therapy remains insufficient to meet the increasing needs of aspiring professional horticultural therapists, new opportunities are developing to meet those needs, most recently at Western Piedmont Community College and at the Univ. of Florida.

A contributing factor to this dirth of educational offerings is the absence of a textbook specific to horticultural therapy. It is anticipated that this need will be resolved soon, however, since professionals in the field are currently preparing a textbook. Upon its availability, it is anticipated that the doors will be opened to additional course offerings at other institutions.

\section{The making of an association}

In 1973, Earl Copus, director of the Melwood Horticultural Training Center in
Upper Marlboro, Md. (a training center for people with developmental disabilities), gathered 20 individuals who were significantly involved in horticultural rehabilitation therapy. The intent of this gathering was to evaluate the need for an organization to unite all horticultural rehabilitation therapy interests. Emanating from this strategic meeting was the unanimous charge to pursue the development of such an organization. Later that same year, the National Council for Therapy and Rehabilitation through Horticulture, the predecessor of today's American Horticultural Therapy Association (AHTA), was incorporated in Maryland through the efforts of its first director, Diane Relf.

As with every organization, AHTA has evolved and will continue to evolve in direct response to its members and to the influences of the changing environment in which it operates. And just as with any other organization that has grown stable, it is driven by a mission that is current yet reflective of the basic intentions of its founders.

AHTA is dedicated to promoting and encouraging national and international interest in developing horticulture and related activities as a therapeutic and rehabilitation medium, enhancing the professionalism of horticultural therapists, and improving the performance of programs providing horticultural therapy services. AHTA strives to im prove the performance of programs using horticultural activities in human development through communication, coordination, knowledge dissemination, and promotion of education and training.

Today, AHTA is a professional membership organization of about 800 members. It is the only organization in the United States that is devoted to the purpose of advancing the practice of horticulture as therapy to improve human well-being. It is concerned with the professional development and education of horticultural therapy practitioners. It provides professional registration based on academic achievement, work, and volunteer experience. It disseminates program and technical information through publications, regional events, and national conferences. It is a membership-driven organization whose services are implemented by a board of directors, committees, work teams, and a network of regional chapter affiliates. It cosponsors with other horticulture industry organizations-including the Society of American Florists and the American Association of Nurserymen-the annual Congressional Initiatives Award, through which a member of the U.S. Congress is recognized for having sponsored important legislation that benefits persons with disabilities. It manages the Douglas J. Schwartz Memorial Greenhouse Grants 
Program, through which horticultural therapy programs can acquire free or matching-fund greenhouses. It has, since 1982, administered a series of federal vocational grants through which more than 2500 people with disabilities have become gainfully employed in the horticultural industry (Davis and De Rise, 1992 ). AHTA oversees the Friends of Horticultural Therapy, created in 1988 to enhance AHTA's pursuit of its mission and goals, by supporting programming, education, and research in horticultural therapy.

\section{AHTA structure and organization}

AHTA is governed and managed by a board of directors composed of an executive committee, which includes four elected officers (president, vice president, treasurer, and secretary), the immediate past president, the executive director (ex-officio and nonvoting), and 15 at-large elected members. The elected members of the executive committee and the immediate past president serve 2-year terms, and the at-large members of the board serve 3year terms, one-third of which expire each year.

The AHTA board of directors, in an ongoing pursuit of strategic long-range planning, facilitated a planning session in 1992 and initiated an evolution within the structure and organization of AHTA. Previously using a system of inflexible, resource-stretched committees, wherein individual committees often absorbed long- and short-term charges, AHTA adopted a more flexible and responsive big-business model, using strategic areas, each with its own operational (long-term) and developmental (short-term) work teams. The operational work teams pursue ongoing activities that are part of the normal operations and services performed by AHTA. The developmental work teams are given specific objectives that are related directly to one of the long-term goals identified by the elected leadership. These work teams are generally small, often regional in composition, and are given objectives that can be accomplished in 12 months or less through a system of realistically achievable action steps.

Today, AHTA's appointed volunteers are organized into six strategic areas and 33 work teams:

- Structure and organization-two operational work teams and one developmental work team

- Proactive networking-three operational work teams and one developmental work team

- Resource development-two operational and six developmental work teams

- Professional Development-three operational and four developmental work teams
- Public recognition/marketing-two operational and four developmental work teams

- Friends of Horticultural Therapy-three operational and two developmental work teams.

These divisions have enabled the AHTA to use more effectively the talents of its members and to address better the goals and needs of the association.

AHTA offices are located in Montgomery County, Md., within easy transit of federal offices in Washington, D. C., and of the offices of horticultural industry and health care industry organizations located throughout the Washington, D.C., metropolitan area, including the ASHS offices. The AHTA offices operate with a staff of seven full-time employees and broach such primary areas as federal grants administration, membership services, finances, and an information inquiry department. The association's budget in the current fiscal year surpasses $\$ 653,000$.

\section{AHTA membership}

Although most AHTA members are practicing horticultural therapists, the AHTA membership also is comprised of representatives of the horticultural industry including academia, representatives of allied health care associations, researchers, and interested individuals. The AHTA membership is an active membership, participating readily in membership benefits.

AHTA provides its members with an annual Journal of Therapeutic Horticulture, the current editor of which is Richard Mattson; an annual AHTA membership directory, which includes program information in narrative form; and 11 issues annually of the People-Plant Connection newsletter. It hosts an annual professional conference, which will beheld in 1995 in Montréal, Quebec, Canada, in conjunction with the ASHS annual meeting. It holds periodic regional and national training programs and symposia, sells discounted AHTA publications, provides unrestricted use of a toll-free information service, and supports a professional liability insurance program and a professional registration program. An AHTA discount purchase program, through which 20 national companies, firms, and organizations (including Verilux, Storey/ Garden Way Publishing, Shepherd's Garden Seeds, The Haworth Press, Gardener's Supply Company, American Hydroponics, and the American Association of Nurserymen) offer $10 \%$ to $50 \%$ discounts on the purchase of everything from fluorescent lamps to garden seed, gardening tools and equipment, and books on gardening.

Additional opportunities exist for educational pursuits, networking, and the provi

\section{7 he AHTA professional conference will be held in 1995 in Montréal, Quebec, Canada, in conjunction with the ASHS annual meeting.}


7 he $A$ HTA

and registers

horticultural

therapists

through a

voluntary

professional

registration

program. sion of support through AHTA's 10 regional chapters: Carolinas, Delaware Valley, Florida, Golden West, Kansas State Univ., Michigan, New England, Northwest, Ohio, and Texas. Sixteen botanical gardens and arboreta in the United States offer horticultural therapy programming, demonstration accessible gardens, classes, and other opportunities: the North Carolina Botanical Garden. the New York Botanical Garden (offers a' certificate program in horticultural therapy), the Brooklyn Botanic Garden, The Frelinghuysen Arboretum, the Minnesota Landscape Arboretum, Fernwood, the Chicago Botanic Garden, the Atlanta Botanical Garden, the Fairchild Tropical Garden, the Denver Botanic Gardens, Sherman Library and Gardens, the Cleveland Botanical Garden, The Holden Arboretum, the Pittsburgh Civic Garden Center, the Red Butte Gardens and Arboretum, and the Norfolk Botanical Garden.

\section{Professional competency evaluation}

In pursuit of the evaluation of professional competency in these areas of necessary responsibility and performance, AHTA recognizes and registers horticultural therapists through a voluntary professional registration program. This is a peer-review system that ensures professional competency based on academic and professional training, work experience in horticultural therapy, and other professional activities and accomplishments. The current program acknowledges three levels of registration (horticultural therapist registered, horticultural therapist technician, and master horticultural therapist ), which reflect an Association-approved core curriculum (Table 1 ) and an equivalency point system (allowing individuals who do not have degrees in horticultural therapy to qualify for professional registration), and which include defined requirements within the areas of education and experience.

The core curriculum for horticultural therapy that is used by the AHTA Registration Review Board to evaluate applicant academic accomplishments, consists of multiple course options divided into four areas of concentration.

Although this system of professional registration has existed since 1977 and has un dergone the periodic refinements necessary to make it a very successful program, the Association is now pursuing certification (competency testing of qualified applicants), the next logical level of credentials evaluation for the individual horticultural therapist. Working very closely with the National Certification Commission (Chevy Chase, Md.), the association leadership hopes to complete this transition in the next 2 years.

\section{The future of the profession}

Several recent studies of emerging fields and occupations (Feingold and Miller, 1994; Swanson, 1993 ) identified horticultural therapy as an area that should experience rapid growth in the coming decade. Part of the rationalization is that the number of facilities and, therefore, job opportunities should increase as the American population grows older and larger. Another part of the rationalization is that there are 65 million households in the United States where gardening is regularly practiced, and that future therapy and rehabilitation patients and clients will pursue the medical option that encompasses the hobby with which they associate enjoyment. Gardening is an excellent lifelong activity, and as more programs offering horticultural therapy are created or expanded, opportunities- for therapists will grow (Swanson, 1993). In the book Emerging Careers: New Occupations for the Year 2,000 and Beyond, Feingold and Miller (1994) selected horticultural therapy as one of the top 30 new occupations of the future, based on the following criteria:

- It has become increasingly distinguishable in recent years

- It has developed from changing needs in existing areas

- It has become possible because of technology or environmental change;

- It shows growth in numbers of people employed and attending new education and training programs

- It requires more than 2 months' training

\section{The importance of research}

Of the many ways in which the realms of horticultural therapy and horticultural science merge and overlap, research stands out most significantly. The research capacity of the ASHS membership is one of its major strengths. The relative nonoccurrence of research in horticultural therapy, despite its tremendous potential and need, is perhaps horticultural therapy's greatest weakness. The lack of substantive research that supports the efficacy of horticultural therapy is a prime reason that the profession has not grown to its potential (AHTA, 1994).

At the April 1992 national symposium People-Plant Relationships: Setting Research Priorities, researchers and practitioners from around the world met to assess the current state of knowledge of human issues in horticulture and to develop a set of research priorities for this important field. To quote from the foreword written by Diane Relf in the collection of papers from this symposium (Flagler and Poincelot, 1994): 
"An understanding of the psychological, physiological and social responses of people to plants in their environment can be a valuable tool in improving the physical and mental health of individuals and communities .... As the data accumulates, we are given a tantalizing indication of how much more there is to be understood about the human relationship to plants and our need for plants in our environment. There is a feeling of excitement among researchers and educators that we maybe on the frontier of recognizing and utilizing the natural environment for psychological, physiological, and social health, much as the knowledge of the plant's role in medicine and nutrition has contributed to physical health."

Perhaps this is a very appropriate time for ASHS and AHTA to expand their areas of commonality and to work together to fulfil shared needs and goals. Horticultural therapy offers significant opportunities for conducting meaningful research. The need is great.

\section{Consider the overlap}

ASHS already includes human issues in horticulture as one of its research division working groups. Interest within the ASHS membership in this area of research already exists. The need for research in the horticultural therapy element of this area already has been substantiated, not only by AHTA, but also by the Agricultural Research Service of the U.S. Dept. of Agriculture, which determined that people-plant interactions is one of the nine research goals and objectives identified as furthering the competitiveness, environmental sensitivity, and sustainability of the United States production of the plants and services of the green industries (Cathey, 1993).

As well, within ASHS' own strategic plan through the year 2003, the first main opportunity listed under external opportunities and threats is horticulture's connection with human well-being and health. Also within this strategic document is listed a primary goal that AHTA hopes will extend to the knowledge base of horticultural therapy: establish ASHS as the recognized leader in advancing the knowledge and application of horticulture by nurturing the diversity of professionals in horticulture and by serving as the primary source of scientific information for researchers and practitioners.

When our two organizations overlap their educational meetings in the 1995 Montréal activities, we need to take full advantage of the unique opportunity these joint gatherings will provide. Let us learn from one another how we might work together, and how we might achieve our organizations' overlapping goals and aspirations in the process. There is much to be gained by both organizations and, potentially, by all of mankind.

Table 1. Core curriculum (minimum requirements: 78 credits+ 1000-hour internship).

\begin{tabular}{|c|c|c|c|}
\hline $\begin{array}{l}\text { Horticultural } \\
\text { therapy (HT) } \\
(8 \text { credits }+1000 \text { hour internship) }\end{array}$ & $\begin{array}{l}\text { Horticultural } \\
\text { science } \\
(40 \text { credits }) \\
\end{array}$ & $\begin{array}{l}\text { Therapy and } \\
\text { human science } \\
\text { ( } 24 \text { credits) }\end{array}$ & $\begin{array}{c}\text { Management } \\
\text { (6 credits) }\end{array}$ \\
\hline $\begin{array}{l}\text { HT } \\
\text { HT techniques } \\
\text { HT programming } \\
\text { Special topics in HT } \\
\text { Internship }\end{array}$ & $\begin{array}{l}\text { Horticulture } \\
\text { Plant propagation } \\
\text { Plant materials } \\
\text { Greenhouse or nursery } \\
\text { production/management } \\
\text { Landscape design/construction } \\
\text { Botany } \\
\text { Soil science } \\
\text { Entomology } \\
\text { Plant pathology } \\
\text { Plant physiology } \\
\text { Fruit and vegetable crops/ } \\
\text { gardening }\end{array}$ & $\begin{array}{l}\text { Introduction to psychology } \\
\text { Abnormal psychology } \\
\text { Sociology } \\
\text { Special courses } \\
\text { Physical disabilities } \\
\text { Developmental disabilities } \\
\text { Emotional disabilities } \\
\text { Geriatrics } \\
\text { Corrections } \\
\text { Psychiatric } \\
\text { Community based programs } \\
\text { Multiple disabilities } \\
\text { Group/process } \\
\text { Counseling } \\
\text { Vocational } \\
\text { Rehabilitation } \\
\text { Special education } \\
\text { Recreation } \\
\text { Therapy skills and services } \\
\text { Psychology } \\
\text { Anatomy/physiology } \\
\text { Sign language } \\
\text { First aid/CPR } \\
\text { Crisis intervention }\end{array}$ & $\begin{array}{l}\text { Communication and } \\
\text { public speaking } \\
\text { Research methods / } \\
\text { statistics } \\
\text { Computers } \\
\text { Business management/ } \\
\text { economics }\end{array}$ \\
\hline
\end{tabular}




\section{Literature Cited}

American Horticultural Therapy/Association. 1994. Introduction: Without validation through research, HT cannot reach its potential. People-Plant Connection. 4 Sept.

Cathey, M. 1993. Executive summary: National chair for florist and nursery crops review 19911993. U.S. Dept. of Agr.-Agr. Res. Serv.

Davis, S. 1994a. Ninth annual congressional initiatives award ceremonies. 19 Apr. Senate Russell Office Building,Washington, D.C.

Davis, S. 1994b. Therapy in the garden for people of all ages. American Hort. July:32-33.

Davis, S. and M. De Rise. 1992. Horticulture hiring people with disabilities. HortTechnology 2:183-189.
Feingold, S. and N. Miller. 1994. Emerging careers: new occupations for the year 2000 and beyond. Garrett Park Press, Garrett Park, Md.

Flagler, J. and R. Poincelot. 1994. People-plant relationships: setting research priorities. Food Products Press, The Haworth Press, New York.

O'Conner, A. 1958. Horticulture as a curative. The Cornell Plantation 14(2):42.

Relf, D. 1992. Human issues in horticulture. HortTechnology 2:159-171.

Swanson, B. 1993. Careers in health care. National Textbook Co., Ridgewood, N.J.

Tereshkovich, G. 1975. Horticultural therapy: A review. National Council for Therapy and Rehabilitation through Horticulture, lecture and publication series. Feb. 1(1):14. 